[Nippon Nôgeikagaku Kaishi Vol. 53, No.6, pp. 197 202, 1979]

\title{
アワビ肝脺臓中のフコイダン分解酵素につレて
}

\section{（2） CM-セルロース吸着画分}

\author{
富士川龍郎，小藪浩二郎*，和田正太** \\ (九州大学農学部食䊓化学工学科)
}

昭和 53 年 12 月 11 日受理

\begin{abstract}
Enzymes in Hepatopancreas of Abalone, Active on Fucoidan ${ }^{\dagger}$
\end{abstract}
(2) Enzyme Fraction Adsorbed on CM-Cellulose

Tatsuo FUJIKAWA, Kōjirō KOYABU** and Masafuto WADA**

Department of Food Science and Technology, Faculty of Agriculture, Kyushu University, Hakozaki, Higashi-ku, Fukuoka 812

\begin{abstract}
A fraction (Enzyme II) of fucoidan degrading enzymes in hepatopancreas of abalone was found to be adsorbed on CM-cellulose.

Both fucoidanase- and fucoidan sulfatase-activities of Enzyme II were eluted in the same elution range from $\mathrm{CM}$-cellulose column by gradient elution. Separation of both activities of the fraction was unsuccessful by the treatment with acid, alkali, or heat. The properties of both fucoidanase- and fucoidan sulfatase-activities of Enzyme II were similar to those of Enzyme I reported previousiy. However, the degradation of fucoidan with Enzyme II stopped earlier and the components of its degradation product with Enzyme II were slightly different from those with Enzyme I in their proportions, though the main products by degradation with both Enzyme I and II were neutral oligosaccharides.

Based on these observations, it is considered that Enzyme II contains the fucoidanase, which degrades fucoidan to oligosaccharides but not to fucose, and the fucoidan sulfatase. These enzymes will be also useful for structural study of fucoidan.

† Studies on Fucoidan and Fucoidan Analogues, Part VI, for Part V: see Ref. (1).

* Present address : The Research Laboratories Ueno Pharmaceutical Co., Ltd., Higashi Arioka 1-127, Itami-shi 664

** Present address : Kasumigaoka 6-25-5, Higashi-ku, Fukuoka 813
\end{abstract}

(Received December 11, 1978)

緒 言

前報(1)では，アワビ肝脺臓中のフコイダンに作用する 酵素が $\mathrm{CM}$ 七ルロースに吸着する画分と吸着しない画 分化分忖られ，かつそれぞれがフコイダナーゼとフコイ ダンスルファターゼ活性をむつことを認め, さらにCMセルロースに吸着しない画分の性質を検討した。

本報で CM-セルロースに吸着する画分の性質を検

†フコイダンおよびフコイダン様多桾の研究（第 6

報)，前報: 文献 1 .

* 現在，上野淛薬株式会社研究所

**現在, 福岡方東区香住ヶ丘 6-25-5
討した。

なお，本報では前報(1) と同しく醉素名を次のように定 義して事く。

フコイダナーゼ:フコイダンのダりコシド結合を加水 分解して還元性の糖または糖誘導体を作る酵素.

フコイダンスルファターゼ：フコイダンまたは各の部 分分解物の酼酸工ステ儿を加水分解して，碳酸イオンを 遊離さ也る䤃素。

方法

1. 材料 アワビ肝脺蔵：市沮のマダカアワビ Haliotis gigantea Gumerin 主に用いたが，一部ク 
ロアワビ $H$. discus Reeve が混入 していた。

基質： 前報(1)に記載したのと同 じモ゙クフュイダンを，1M 塩酸-

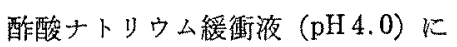
$0.5 \%$ に溶かしたものを基質とした。 条件が異なる時は別に記载する。

\section{2. 一般方法 蛋白诈之糖の检} 出と定量法：カラムクロマトグラ フィ一の場合, 蛋白質は溶出液の $280 \mathrm{~nm}$ の吸収により検出し，その 他の場合はケルダール法または銅一 Folin 法 ${ }^{(2)}$ にり蛋白筫を定量し た.

全樍はフェノール・硫酸法 ${ }^{(3)} に よ$ り，道元䊅は Somogyi-Nelson 比 色法(4)により定量した。

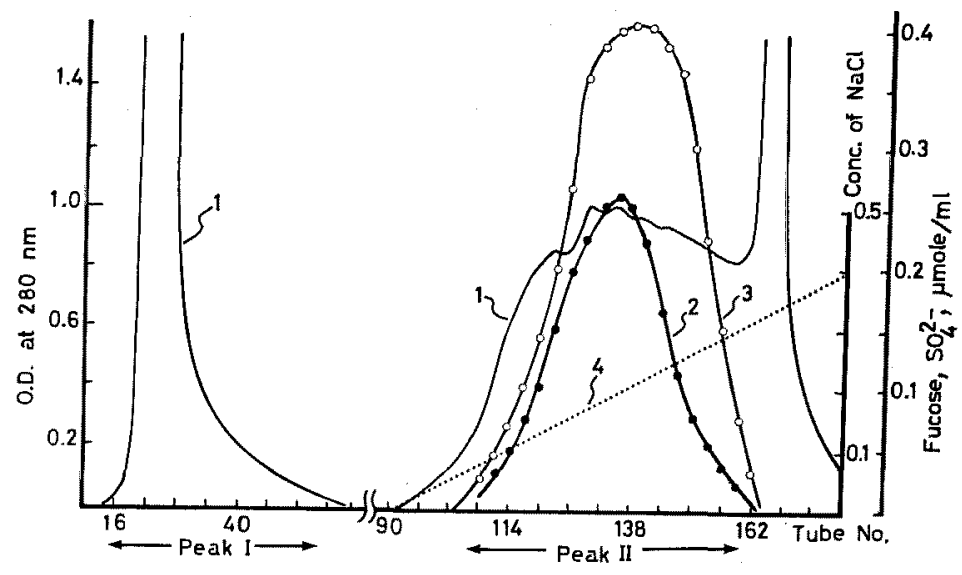

Fig. 1. Chromatogram of the Crude Enzyme on a CM-Cellulose Column. Column : $3.2 \times 33 \mathrm{~cm}$, Equilibrated with $0.02 \mathrm{M} \mathrm{HCl}-$ $\mathrm{NaOAc}$ buffer soln. (pH 5.0). One tube : $10 \mathrm{ml}$. Assay for activity : $0.5 \%$ fucoidan ( $\mathrm{pH} 4.0) 2 \mathrm{ml}$ effluent $3 \mathrm{ml}, 40^{\circ} \mathrm{C}, 20 \mathrm{hr} .1$ : O. D. at $280 \mathrm{~nm}, 2:$ fucose, $3: \mathrm{SO}_{4}^{2-}, 4:$ concentration of $\mathrm{NaCl}$. 2 and $3: \mu$ mole per $1 \mathrm{ml}$ of the reaction mixture.

防腐：本実験の酵素反心は長時間を要するので,反 応液には常にトルエンを数滴加えた。

3. 粗酵素の調製(1) アワビ肝膵葴のホモジネート より, 硫安 $30 \%$ 飽和で生成する沈殿を除いた後，上清 より硫安 $50 \%$ 飽和で生成する沈殿を集め，水に溶かし て透析し， $38^{\circ} \mathrm{C}, 16 \mathrm{hr}$ 放置して生じた沈殿走除いた。 この上清液より，エタノ一几濃度 $80 \%(\mathrm{v} / \mathrm{v})$ で沈殿す る画分を集め，アセトンで洗浄後減圧下で乾燥したるの を粗醇素として用いた。

4. フコイダナーゼ活性測定法 前報 ${ }^{(1)}$ と同じ方法

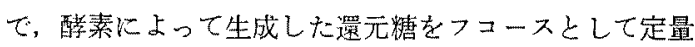
し，醅弥液の活性とした。

5. フコイダンスルファターゼ活性測定法 前報(1) と同じく被梌液と盲検液をそれぞれ稀塩酸で $\mathrm{pH} 3 \mathrm{KL}$ て遠心分離し，上清の一定量に $0.3 \mathrm{M} \mathrm{BaCl}_{2}$ 女加えた後 定容積とし，両者の660 nm の吸收から硫酸イオン濃度 を算出し，盲検值を差引いた値を酵素によって生成した 硫酸イオンとした。

雨活性はそそれぞれ相対活性または一定時間での生成量 で表わした。

\section{実験上結果}

\section{CM-セルロースによる粗醏素の分画, 酵素 II}

粗醳䋕液 $75 \mathrm{ml}$ (全蛋白質 $1.39 \mathrm{~g}, 0.02 \mathrm{M}$ 塩酸一酷酸 ナトリウム緩衝浓に溶かしたもの)を,同じ緩衝液と平衡

させた CM-セルロースカラム $(3.2 \times 33 \mathrm{~cm})$ に負荷し， 同緩衝液で非吸着画分を溶出させせた後，緩衝液に加えた $\mathrm{NaCl}$ 惯度を0より $0.5 \mathrm{M}$ で昇させる gradient elution を行った．溶出液は 1 tube 当り $10 \mathrm{ml}$ ずつ集 めた．蛋白質の溶出曲線を Fig. 1 の曲線 1 k示す. Peak

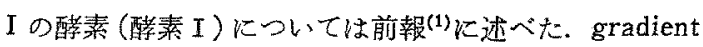
elution の部分に溶出する画分のうち，tube No.108〜 162 の部分にフコイダナーゼとフコイダンスルファター ゼ活性が認められ（曲線 2 と3），から両活性の最大ピ 一クの位置もほとんど同じである. tube No. 158〜180 の部分には醳素活性は認められなかったが，着色物がこ

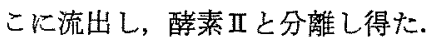

\section{Peak II の再クロマトグラフィー}

Fig. 1 の Peak II (tube No. 105〜155) の部分を䈎め た.この画分は， $\mathrm{pH} 4.0,38^{\circ} \mathrm{C}$ でインキュベートする と酵素液自体より還元性物質を生成した。これを除くた め, 溶出液をコロジオンバッグで濃繀し, $\mathrm{pH} 4.0,38^{\circ} \mathrm{C}$, 12 時間インキュペートし, 生じた白沈を除き, $\mathrm{pH} 5.0$ の 塩酸一酢酸ナトりウム緩衙液 $(0.02 \mathrm{M})$ に対して透析し た後に試料とした。この試料を同じ緩衝液と平衡させた CM-セルロースカラム $(3.2 \times 33 \mathrm{~cm})$ に負荷し, 前と同 じ方法で gradient elution を行った. 溶出液は 1 tube 当り $10 \mathrm{ml}$ ずつ集かた。蛋白質と雨活性の溶出を Fig. 2 に示す. Fig. 2 の tube No. 52〜78 の画分を集め,

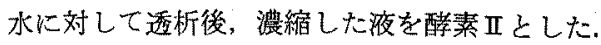




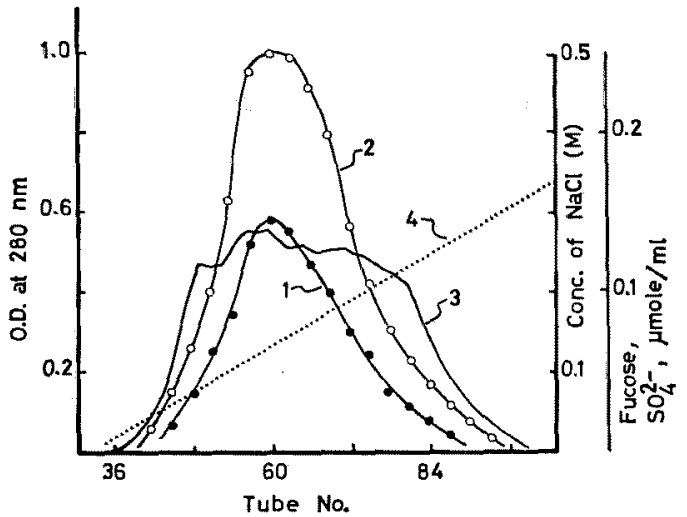

Fig. 2. Rechromatography of Peak II of Fig. 1 on a CM-Cellulose Column. A effluent of Peak II of Fig. 1 was used as Enzyme II soln. after incubation at $40^{\circ} \mathrm{C}$ for $12 \mathrm{hr}$, followed by concentration and subsequent dialysis against 0.02 M HCl-NaOAc buffer soln. (pH 5.0). Conditions for chromatography : see Fig. 1. 1 : fucose, $2: \mathrm{SO}_{4}{ }^{2-}, 3: \mathrm{O}$. D. at $280 \mathrm{~nm}, 4:$ concentration of $\mathrm{NaCl}$. 1 and $2: \mu$ mole per $1 \mathrm{ml}$ of the reaction mixture.

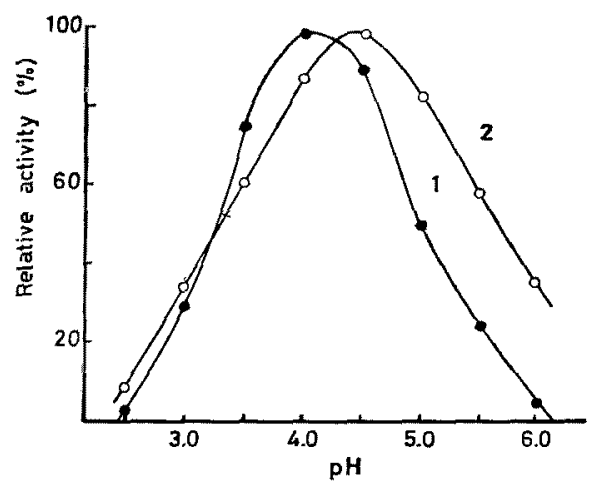

Fig. 3. Effect of $\mathrm{pH}$ on Activities of Enzyme II. Incubation : Enzyme II soln. $2 \mathrm{ml}+0.5 \%$ fucoidan (water soln.) $1 \mathrm{ml}+0.5 \mathrm{M} \mathrm{HCl}-\mathrm{NaOAc}$ buffer soln. (pH 2.5 6.0) $1 \mathrm{ml}, 38^{\circ} \mathrm{C}, 24 \mathrm{hr}$. $\mathrm{pH}$ : $\mathrm{pH}$-value of the buffer soln. used. $100:$ maximum activity obtained. 1 : fucoidanase, 2 : fucoidan sulfatase.

\section{3. 酵素 II の性質}

酵素活性の $\mathrm{pH}$ 依存性 : 醅素开 $2 \mathrm{ml}, 0.5 \mathrm{M}$ 塩酸一

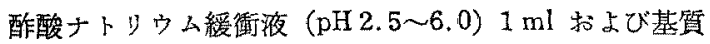
$1 \mathrm{ml}$ を加克， $38^{\circ} \mathrm{C} ， 24$ 時間インキュベートした後，澴 元糖と硫酸イオン定量した。得られた最大活性を 100 として相対活性と pH との関係圭 Fig. 3 に示す.フコイ

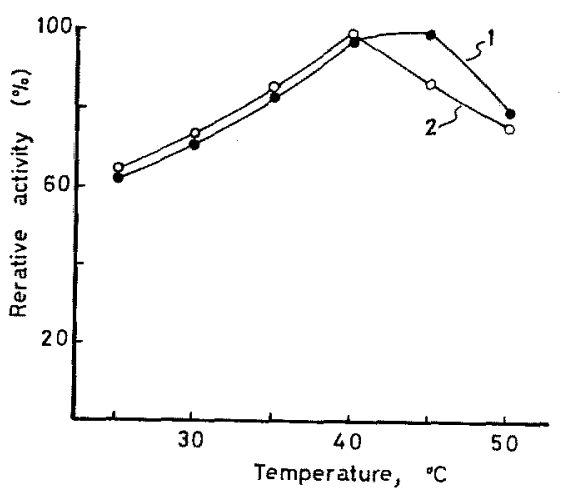

Fig. 4. Temperature-Activity Curves of Enzyme II. Incubation : $\mathrm{pH} 4.0,25 \mathrm{hr} .100$ : maximum activity obtained. 1 : fucoidanase, 2 : fucoidan sulfatase.

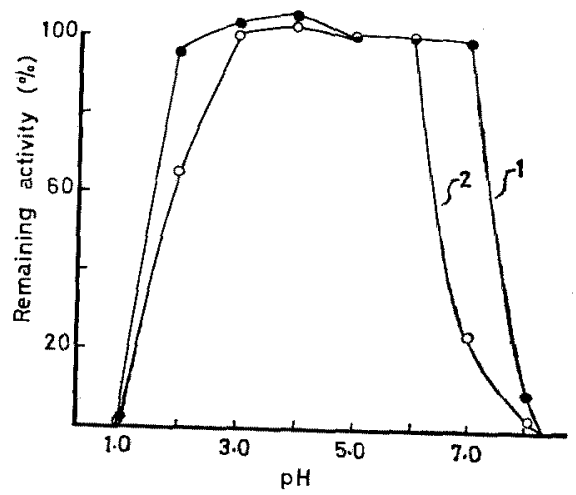

Fig. 5. pH-Stability of Enzyme II. Enzyme II was allowed to stand for $24 \mathrm{hr}$ at $20^{\circ} \mathrm{C}$ after adjustment of pH as shown in Fig. 5, and then remaining activity was estimated. 100 : activity. before treatment. 1 : fucoidanase, 2 : fucoidan sulfatase.

ダナーゼとフコイダンスルファターーゼの至適 $\mathrm{pH} は$ はれ ぞれ 4.0 と 4.5 の付近に認められる。

至適温度：酳素液 $2 \mathrm{ml}, \mathrm{pH} 4.0,0.5 \mathrm{M}$ 塩酸一酢酸 ナトリウム緩衙液 $1 \mathrm{ml}$, および基質溶液 $1 \mathrm{ml}$ ※混合 し，25〜 50 C の範团で 25 時間インキュペートした。 得 られた最大活性を 100 として相対活性と温度との関係を

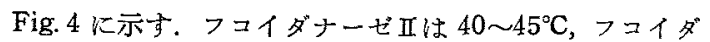
ソスルファターゼは $40^{\circ} \mathrm{C}$ 付近に至適温度が認められる

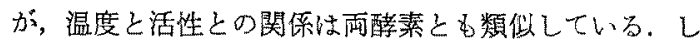

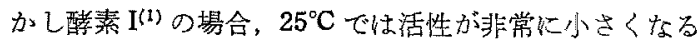

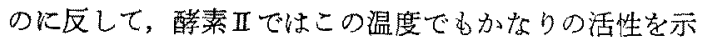
している. 


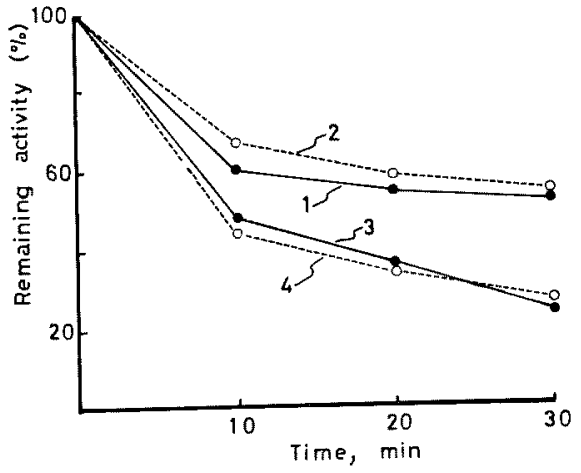

Fig. 6. Thermal Stability of Enzyme II. Thermal treatment: Enzyme II soln. ( $\mathrm{pH} 4.0)$ was heated at 60 or $65^{\circ} \mathrm{C}$ for 10,20 , and $30 \mathrm{~min}$, cooled in ice water, and then remaining activity was estimated. 100 : activity before the treatment. $60^{\circ} \mathrm{C}, 1$ : fucoidanase, 2 : fucoidan sulfatase. $65^{\circ} \mathrm{C}, 3$ : fucoidanase, 4 : fucoidan sulfatase.

pH-安定性：醉素而を稀塩酸または稀 $\mathrm{NaOH}$ によ b $\mathrm{pH} 1 \sim 10$ に調節し， $20^{\circ} \mathrm{C} ， 24$ 時間放置後, $\mathrm{pH}$ t 4.0 にもどし，残存活性を測定した，処理前の活性を 100 として残存した相対活性と $\mathrm{pH}$ との関係を Fig. 5 に 示寸. 雨活性とも $\mathrm{pH} 2$ 以下 7 以上（フコイダンスルフ ァターセは6以上）で恃著しく不安定であり，酵素 ${ }^{(1)}$ に比べると両活性ともかずかではあるが安定域がより酸 性側に古る。な和 pH3〜4の間で残存活性が 100\%を やや上回っている。こ机必与゙しも測定誤差ではないよ らに思われるが，この点に関してはまだ㛟討していな 6.

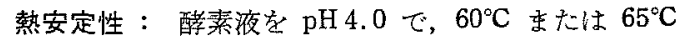
に 10,20，30 分加熱した後，残存与る活性を測定し た. 熱処理前の活性を100として，残存した活性と加熱 時間との関係をFig. 6 に示す.フコイダナーゼとフコイ ダンスルファターゼとの間で熱安定性の差は認められな い. ま $70^{\circ} \mathrm{C}, 10$ 分の加熱では両活性ともほぼ完全に 失活した，酵素 $I^{(1)}$ の場合に比べると，酵素は両活性 とも熱に対してやや不安定であった。

\section{4. 酳 II によるフコイダン分解の経時变化}

酵素 II $20 \mathrm{ml}$ K $1 \%$ フコイダン溶液 (pH 4.0,0.5 M 塩 酸一酶酸ナトリウム緩衝液に溶解) を $20 \mathrm{ml}$ 加古た液と， 同じ緩衝液を $20 \mathrm{ml}$ 加之た液とを $40^{\circ} \mathrm{C} て ゙ 98$ 時間なで インキニベートした，一定時間挔に雨混合物中に生成 した還元糖と硫酸イオンを定量し，酵素によるそれぞれ

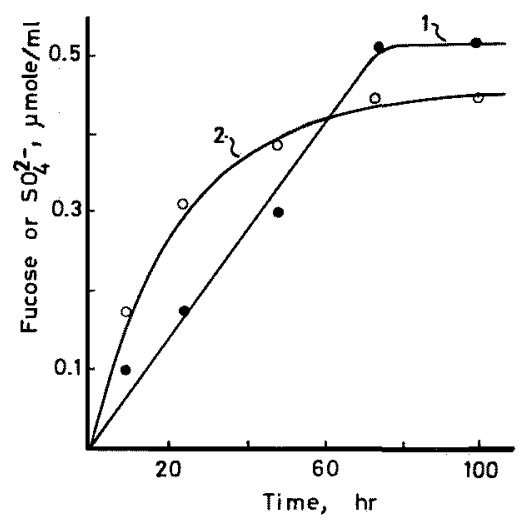

Fig. 7. Time Course of Liberation of Fucose and $\mathrm{SO}_{4}{ }^{2-}$ with Enzyme II. Incubation : pH4.0, $40^{\circ} \mathrm{C}$. 1 : fucose, $2: \mathrm{SO}_{4}{ }^{2-}, \mu$ mole per $1 \mathrm{ml}$ of the reaction mixture.

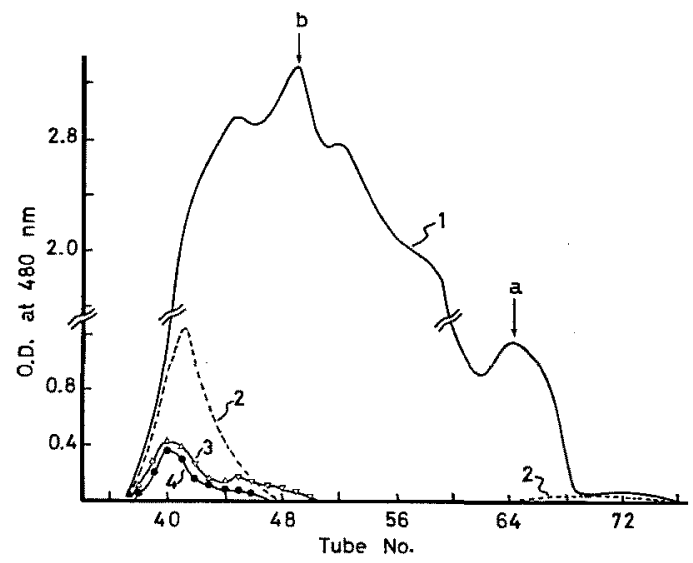

Fig. 8. Gel Filtration of Digestion Product of Mozuku-Fucoidan with Enzyme II, Digestion : $40^{\circ} \mathrm{C}, 53 \mathrm{hr}$. Column : Sephadex G-15 (1.7 $\times 89$ $\mathrm{cm})$. Eluent : water. One tube $: 2 \mathrm{ml}$. Detection : phenol-sulfuric acid method. Neutral sugar fraction, 1: Enzyme II+fucoidan, 2: only Enzyme II. Acidic sugar fraction, $3:$ Enzyme II +fucoidan, 4 : only Enzyme II. Peak a and b : see the text and compare with Fig. 12 in Ref. (1).

の生成眭を求めた。結果を Fig. 7 に示す.70 時間まで

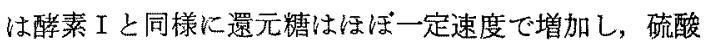
イオンは次第に速度を減じながら增加していく７0 時

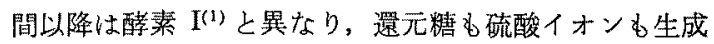
はほぼ停止している，98時間までに生成した還元糖は フコースとして $0.51 \mu \mathrm{mole} / \mathrm{ml}$, 硫酸は $0.44 \mu \mathrm{mole} / \mathrm{ml}$ であり，分解率は全フコシド結合の $3.6 \%$, 全ェステル 
硫酸の $2.6 \%$ である．たたし基質のフコースと硫酸基の 含量はそれぞれ $46.9 \% ， 32.9 \%$ である.

\section{5. 酳素 II による分解生成物}

酵素 II $10 \mathrm{ml}$ と $1 \%$ フコイダン溶液 $(\mathrm{pH} 4.0,0.5 \mathrm{M}$ 塩酸一醀酸ナトリゥム緩衝液に溶解） $5 \mathrm{ml}$ の混合液，招 よび醳素全 $10 \mathrm{ml}$ と上と同じ緩衝液 $5 \mathrm{ml}$ の混合液をそ れぞれ $40^{\circ} \mathrm{C} ， 22$ 時間と 53 時間インキュヘートした。 この両混合液を $100^{\circ} \mathrm{C}, 2$ 分加熱して生じた沈影を除き， 上清をDowex-1 $\left(\mathrm{CO}_{3}{ }^{2-}\right)$ のカラムに通して院イオンを 吸着さ世，非吸着画分と吸着画分火分けた，非吸着画分 は集めて塩酸で中和し，濃縮乾涸して中性糖画分とし， 吸着画分は $3 \mathrm{M}$ 塩酸で溶出し，溶出液を $\mathrm{NaOH}$ で中和 し濃縮乾沼して酸性精画分とした，それぞれを $3 \mathrm{ml} の$ 水に溶か乙, Sephadex G-15 の为ラム $(1.7 \times 89 \mathrm{~cm})$ K 負荷し，水で溶出し，溶出液は $2 \mathrm{ml}$ ずつ集めてフェ， 一ル・硫酸法 (3)によって糖を検出定量した。 53 時間の 場合の溶出曲線を Fig. 8 飞示す. Fig. 8 の tube No. 68 〜76の小ピークは単糖の溶出位置であり，酸素 II 自体 からもわずかではあるが単糖の生成が認められる。した がって Fig. 8 曲線 1 のこ位置の小ピータは醇素由来の ものと考えられる. tube No. 37〜44 の溶出ピークは酵 素または末分解のフコイダンであるので，以後の考察に は入れない。この溶出曲線を前報醉素 $I^{(1)}$ の場合と比べ ると，中性精の主溶出部が tube No. 44〜68 に現われて いる点は同じであるが, Peak a (tube No. 64 付近) と Peak b (tube No. 49 付近) 加比較的著しいこと, 酸性 糖の画分に tube No. 48〜53 の溶出が顕著でない点が巽 なっている。22 時間分解の場合は，中性精画分の溶出 ピークの主要部は 53 時間分解の場合に比べて高分子側 にあり，Peak a は影著でなく，酸性糖画分の溶出曲線 は 53 時間分解の場合（曲線 3 ） と同じパターンを示し た.

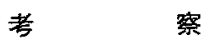

アワビ朋脺臓中のフコイダン分解酵素は，CM-セルロ

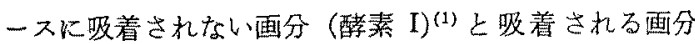

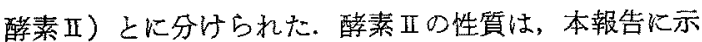
されたよらに，CM-七ルロースに対する笔勤以外は醉素 Iに類似している(1)，したがって前報で酵猄 Iに関して

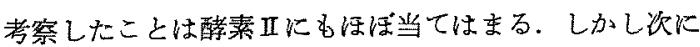
述べるような等少の差異は認められる，以下酵慗の コイダナーゼ, フコイダンスルファターゼをそれぞれフ
コイダナーゼI，フコイダンスルファターー゙I正とし，酵 素エについても同様儿称する.

まず $\mathrm{pH}$ 安定性は，フコイダナーゼIの安定域が $\mathrm{pH}$ 4.0〜7.0であるのに比べて，フコイダナーゼ II は pH 2.0〜7.0 と酸性側で安定であり，フコイダンスルファ ターゼIでは pH 3.0〜7.0であるのに対してフコイダ ソスルファターセ゚IIでは pH3.0〜6.0とフルカリ侧で不 安定である。

至適温度は醉菜而の両活性では酵素 I(1)のそれに比べ てやや高温側にある。しかし，30 両活性はともに約 $25 \%$ 低下する(1)のに比べて，醉素 II の兩活性の低下は約 $60 \%$ に低下するにすぎない点に特 徽が認められる。

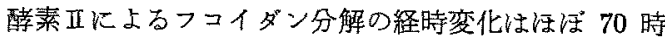
間までは䤃素 I の場合上同様な経過をたよ゙るが，それ以 後は還元栯と硫酸イオンの增加が注ぼ停止する点が異な っている.98 時間での分解率は前速のようにフコシド 結合の $3.6 \%$ ，エステル硫酸の $2.6 \%$ と酵素Iより小さ

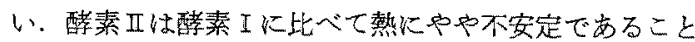
からみて，酵素吕の活性が低いことと反応が早く停止す ることは醉菜の失活に基つくよらに思われる。

分解生成物（53 時間分解）に関しては，遊離フコース はごくかずかしか生成していないことは酵素 Iと同じで あり，かつ粗酳之は異なる点であるが，な特次のよ5 な特徽が諗められる，中性糖画分ではピータb (Fig. 8) が比較的㫫著に認好られ，酵素Iの場合溶出曲線が全体 にブロードであるのと異なっている（前報 Fig. 12(1)）。 次にピーク、 (Fig. 8) が明瞭に表われている。これは酵 素 I の場合，ピーク a のすぐ前の位置（前報 Fig. 12， tube No. $\left.60^{(1)}\right)$ に一つの画分の溶出があるが，醅素 場合にはこれがないためピーク、が目立っていると思わ れる。亦た，22 時間分解に比べて 53 時間分解では溶出 の最大ピークの位圆が低分子側に和動し，ピークbは 22 時間分解では明瞭には現われなかった。したがって酵素

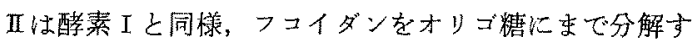
可醋素を含さが，フコースにまで分解する酵素は除かれ

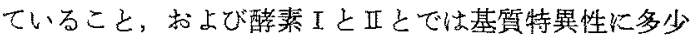
の差があるとが考劣られる。

酸性画分については，酸素

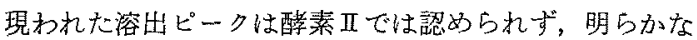
差を示し\%。

以上のようにみてくると，醉素开は基質特異性が酵素 
I(3) とは異なる醭素を含さことが考光られ，したがって， 精製法の改良によって活性の高い酵素標品を得ることが できれば，酵素 I と相補ってフコイダンの構造研究に有 力な手段を提供することが期待される。

\section{要約}

アワビ肝膵臓に存在し，フコイダンを分解する酵素の らち，CM-七ルロース吸着画分（䤃素I）について検討 した、酵素IIつコイダナーゼとフコイダンスルファタ 一ぜ活性は， $\mathrm{CM}$ 一ルロースカラムより $\mathrm{NaCl}$ を用いた gradient elution で $0.3 \mathrm{M}$ までに，同じ溶出位置に溶 出され，分離できなかった。両活性の $\mathrm{pH}$ と熱に対する性 質は互いに類似していて，一方の活性のみを $\mathrm{pH}$ あるい

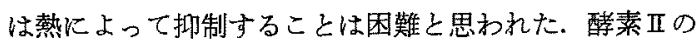
性質は，CM-セルロースに対する学動以外は，醅素 I
（CM-セルロース非吸着画分）の性貿に類似していたが， 䤃菜Iに比べて早く反応が止まることと, 生成した中性 オリゴ糖の種類およびそれらの比率には多少の差がある ことが認められた。

これらより，酵素II の基質特異性は酵素 I とは異なる 点があり，したがって酔素 I とともにフコイダンの構造 研究に有力な手段を提供するるの之考えられる.

（1）富士川龍郎，小敏浩二郎，和田正太 : 濃化, 53, 87 (1979).

（2）赤堀四郎縟：醉丵研究法 I, 朝倉書店, 東京, 1968, p. 166.

(3) M. Dubois, K.A. Gibbes, J. K. Hamilton, P.A. Robers and F. Smith : Anal. Chem., 28, 350 (1956).

(4) M. Somogyi : J. Biol. Chem., 195, 19 (1952). 